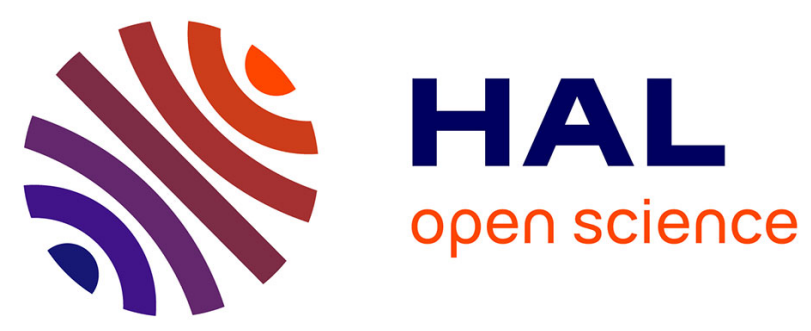

\title{
Terrestrial Permian-Triassic boundary in southern \\ China: New stratigraphic, structural and palaeoenvironment considerations
}

Sylvie Bourquin, Camille Rossignol, Marc Jolivet, Marc Poujol, Jean Broutin, Jianxin $\mathrm{Yu}$

\section{To cite this version:}

Sylvie Bourquin, Camille Rossignol, Marc Jolivet, Marc Poujol, Jean Broutin, et al.. Terrestrial Permian-Triassic boundary in southern China: New stratigraphic, structural and palaeoenvironment considerations. Palaeogeography, Palaeoclimatology, Palaeoecology, 2018, 490, pp.640-652. 10.1016/j.palaeo.2017.11.055 . insu-01647545

HAL Id: insu-01647545

https://hal-insu.archives-ouvertes.fr/insu-01647545

Submitted on 24 Nov 2017

HAL is a multi-disciplinary open access archive for the deposit and dissemination of scientific research documents, whether they are published or not. The documents may come from teaching and research institutions in France or abroad, or from public or private research centers.
L'archive ouverte pluridisciplinaire HAL, est destinée au dépôt et à la diffusion de documents scientifiques de niveau recherche, publiés ou non, émanant des établissements d'enseignement et de recherche français ou étrangers, des laboratoires publics ou privés. 


\section{Accepted Manuscript}

Terrestrial Permian-Triassic boundary in southern China: New stratigraphic, structural and palaeoenvironment considerations

Sylvie Bourquin, Camille Rossignol, Marc Jolivet, Marc Poujol, Jean Broutin, Jianxin Yu

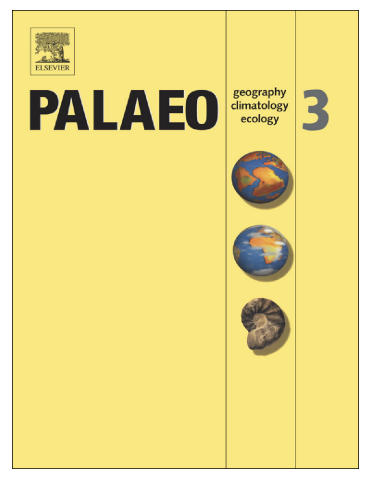

PII: $\quad$ S0031-0182(17)30326-7

DOI: $\quad$ doi:10.1016/j.palaeo.2017.11.055

Reference: $\quad$ PALAEO 8557

To appear in: Palaeogeography, Palaeoclimatology, Palaeoecology

Received date: $\quad 24$ March 2017

Revised date: $\quad 22$ November 2017

Accepted date: 23 November 2017

Please cite this article as: Sylvie Bourquin, Camille Rossignol, Marc Jolivet, Marc Poujol, Jean Broutin, Jianxin Yu , Terrestrial Permian-Triassic boundary in southern China: New stratigraphic, structural and palaeoenvironment considerations. The address for the corresponding author was captured as affiliation for all authors. Please check if appropriate. Palaeo(2017), doi:10.1016/j.palaeo.2017.11.055

This is a PDF file of an unedited manuscript that has been accepted for publication. As a service to our customers we are providing this early version of the manuscript. The manuscript will undergo copyediting, typesetting, and review of the resulting proof before it is published in its final form. Please note that during the production process errors may be discovered which could affect the content, and all legal disclaimers that apply to the journal pertain. 


\title{
Terrestrial Permian-Triassic boundary in southern China: new
}

\section{stratigraphic, structural and palaeoenvironment considerations}

\author{
Sylvie Bourquin $^{\text {a* }}$, Camille Rossignol ${ }^{\mathrm{a}, \mathrm{b}}$, Marc Jolivet ${ }^{\mathrm{a}}$, Marc Poujola ${ }^{\mathrm{a}}$, Jean Broutin ${ }^{\mathrm{c}}$, \\ and Jianxin $\mathbf{Y u}^{\mathrm{d}}$
}

${ }^{a}$ Géosciences Rennes, UMR 6118 CNRS, OSUR, Université de Rennes 1, 35042 Rennes

cedex, France.

*Corresponding author: sylvie.bourquin@univ-rennes1.fr

b APPLIED ISOTOPE RESEARCH GRoup, DEPARTAMENTO DE GEOLOGIA, UNIVERSIDADE FEDERAL DE OURO PRETO, MG 35400000, BRAZIL

${ }^{c}$ Sorbonne Universités, Paléobotanique \& Paléoécologie, CR2P, UPMC Paris 6 - MNHN CNRS, F-75005 Paris, France.

${ }^{d}$ State Key Laboratory of Biogeology and Environmental Geology, China University of Geosciences, Wuhan 430074, People's Republic of China.

\begin{abstract}
The Permian-Triassic boundary is located above the main Phanerozoic terrestrial and marine biotic crisis. Southwest China (eastern Yunnan and western Guizhou) is considered as an ideal place in Asia to study the terrestrial Permian-Triassic boundary, its correlation with the stratigraphically equivalent marine deposits, and to discuss the contemporaneity between the marine and terrestrial extinctions. The Chahe and Zhejue sections, which have already been studied in detail, especially using $\delta{ }^{13} \mathrm{C}$ isotopic analyses for both sections and geochronology for the Chahe section, are considered to be the reference terrestrial sections to discuss changes (both through time and space) in macroflora, pollen diversity and paleoenvironment. Based on new structural analyses of these sections, we demonstrate that
\end{abstract}


they have been strongly affected by polyphase deformations and are, therefore, not suitable to discuss the vertical and/or lateral evolutions of the depositional environments within the Permian-Triassic succession. The use of the Chahe and Zhejue sections to study the contemporaneity between marine and terrestrial extinction events at the end of the Permian in southern China, as well as the stratigraphic correlations and the palaeoenvironment reconstitution of western Guizhou and eastern Yunnan, therefore, must be reconsidered.

\section{Keywords}

Eastern Yunnan; Western Guizhou; Xuanwei Formation; Kayitou Formation; Sedimentological section.

\section{Introduction}

South China is known for its well-preserved marine Permian-Triassic boundary (PTB) sections, especially that of Meishan in Zhejiang Province (Fig. 1) (e.g. Yin et al., 2001). Additionally, southwest China (eastern Yunnan and western Guizhou) is also considered as an ideal place to investigate the terrestrial Permian-Triassic boundary (Peng et al., 2005, 2006; Zhang et al., 2006; Yu et al., 2007, 2010; Shen et al., 2011; Vajda and Bercovici, 2014; Bercovici et al., 2015; Zhang et al., 2016), to study the transition from terrestrial to marine facies, and to provide correlations with the Meishan marine section across the Yangtze Platform (Shen et al., 2011; Glen et al., 2009; Peng and Shi, 2009; Wang et al., 2011; Yu et al., 2015; Cui et al., 2016). Among several sections, the terrestrial Chahe and Zhejue sections, located to the south of the Sichuan Basin (Figs. 1 and 2A), are considered as classical sections, especially the Chahe section which is proposed as an equivalent of the Meishan PTB GSSP (Global Stratotype Section and Point). However, both sections are situated in a region strongly deformed during Mesozoic and Cenozoic tectonic events (e.g. Liu et al., 2012; Wang et al., 2013). The effects of deformation are rarely taken into consideration when studying the 
PTB and the sections are usually described as continuous through the Paleozoic - Mesozoic boundary (e.g. Peng et al., 2006; Yu et al., 2007; Bercovici et al., 2015). Here we present the first detailed structural analysis for these two classical sections and we show that deformation affected their stratigraphic continuity. These data allow us to discuss the validity of the supposed position of the PTB in this area and its possible correlation with the marine Meishan PTB GSSP.

\section{Geological setting}

The Permian-Triassic sections classically studied in western Guizhou and eastern Yunnan are located along the northern edge of the Nanpanjiang Basin (Fig. 1), within an area characterized by large NE-SW trending folds and thrust structures affecting both the Proterozoic substratum and the Paleozoic-Mesozoic sedimentary cover (Fig. 2A). To the NE, this deformation correlates with the Mesozoic Daloushan and Xuefeng tectonic belts (e.g. Liu et al., 2012; Deng et al., 2015; Faure et al., 2016) across the major NW-SE trending, leftlateral Ziyun - Luodian fault (Figs. 1, 3A, B). This Paleozoic inherited fault that acted as a top-to-the-NNW thrust during the Triassic was reactivated as a normal fault during the Jurassic. From the Late Jurassic to the Aptian-Turonian, SE China was affected by a compressive regime associated with the Yanshanian orogeny and driven by the subduction of the Izanagi (Paleo-Pacific) oceanic plate along the eastern margin of Asia (e.g. Yan et al., 2003). Before reaching its zenith during the Late Cretaceous with the emplacement of arcrelated magmas along the southeastern margin of China (e.g. Zhou et al., 2006), the Yanshanian orogeny resulted in the formation of a large NE-SW trending fold-and-thrust belt that extends north of the Triassic Nanpanjiang (or Youjiang) Basin up to the Qinling - Dabie orogen (Fig. 1) (e.g. Chen, 1999; Yan et al., 2003; Li and Li, 2007; Richardson et al., 2008). The major faults remained in a left-lateral transpressive regime from the Early Cretaceous to the late Cenozoic (e.g. Wang et al., 2013; Deng et al., 2015). 
With the exception of Bercovici et al. (2015) who reported several small faults and dip-variations in beds from the Chahe section, the paleoenvironments from southwestern China have consistently been reconstructed without considering the deformation and/or the potential discontinuities affecting the succession (Peng et al., 2005, 2006; Zhang et al., 2006; Zhang et al., 2016). In western Guizhou and eastern Yunnan, the terrestrial Upper Permian sedimentary succession unconformably overlies the Emeishan flood basalts (e.g. Peng et al., 2006). Three terrestrial clastic formations, mostly considered as lacustrine-swamp deposits, have been distinguished based solely on their colors (Figs. 2B), namely: the Xuanwei, Kayitou and Dongchuan formations (fms). The coal-bearing Xuanwei Fm, considered as Lopingian-earliest Triassic in age base on plant fossils (Peng et al., 2005, 2006; Yu et al., 2007), is composed of alluvial or shallow lake deposits with some sand-bed river deposits (Yu et al., 2007; Bercovici et al., 2015). The uppermost coal marks the top of the Xuanwei Fm. The overlying Kayitou Fm, lacking any direct chronological constraint, is only dated assuming a stratigraphic correlation with the marine formations to the east, attributed either to the Early Triassic or to the Changhsingian-earliest Triassic transition (see Peng et al., 2006 for discussion). This formation is described as characteristic of a lacustrine (Yu et al., 2007) or a brackish lagoon deposit (Bercovici et al., 2015). Finally, the non-dated Dongchuan Fm is mainly composed of clastic sediments of terrestrial origin deposited in a braided river setting (Bercovici et al., 2015; Zhang et al., 2016). Peng et al. (2006) considered that these successions onlap westward onto an old land mass formed by a Paleozoic and older substratum. Eastward these authors proposed a succession of laterally continuous PTB sections recording a gradual change from terrestrial to marine facies (Fig. 3C).

The exact location of the PTB within the Guizhou and Yunnan sections remains controversial creating uncertainties on the timing of the mass extinction event, the subsequent ecosystems recovery (e.g. Shen et al., 2011; Xiong and Wang, 2011), and the 
contemporaneity between marine and terrestrial extinctions (e.g. Shen et al., 2011; Zhang et al., 2016). From the Chahe and Zhejue sections, Peng et al. (2005) defined an 'eventostratigraphy concept' used for the recognition of events across the PTB-related deposits, called the Permian-Triassic boundary Stratigraphic Set (PTBST; Figs. 4A, 5A). They assumed that the PTB is located at the top of the Xuanwei Fm within a vertical succession of three claystone beds (around $2.5 \mathrm{~m}$ thick at Chahe and $1 \mathrm{~m}$ thick at Zhejue, Figs. 4A, 5A) 'characterized by the vertical stacking of a clay or/and mudstone, followed by a muddy siltstone, again followed by a second clay or/and mudstone bed' that they consider as being similar to those described for the marine PTB at Meishan. This conclusion is reinforced by a similar $\delta{ }^{13} \mathrm{C}$ trend across the PTB between the Chahe and Meishan sections (Peng et al., 2005) as well as sections outside China (e.g. Twitchett et al., 2001). Zhang et al. (2006) attribute a volcanic origin to the claystone beds of the PTBST, which they use as markers for a high-resolution subdivision and the correlation of the PTB from land to marine environments in southern China (e.g. Peng and Shi, 2009). Using paleofloral analyses in sections located further to the east, Yu et al. $(2007,2010)$ observed that the lower Kayitou Fm contains a mixed Early Triassic marine fauna as well as an Early Triassic palynoflora and macroflora. This assemblage includes rare late Permian survivors and Triassic elements (Annalepis), but with lower abundance and diversity above the PTB: the few Gigantopteris flora elements recorded here are considered as surviving taxa that crossed the PTB into the earliest Triassic (Yu et al., 2015; Bercovici et al., 2015). This attribution of the base of the Kayitou Fm to the Early Triassic was based on U-Pb dating of zircon grains from the PTBST in the Chahe section at 252.6 \pm 2.8 and $247.5 \pm 2.8 \mathrm{Ma}$ (Yu et al., 2008; Fig. 4A). Another date, obtained on zircon grains collected in the same PTBST level by Isotopic Dilution Thermal Ionization Mass Spectrometry (ID-TIMS), gave a more precise age of $252.30 \pm 0.07$ 
Ma (Shen Z. et al., 2011). In consequence, Shen et al. (2011) relocated the PTB a few meters above the boundary between the Kayitou and Dongchuan fms (Fig. 4B).

The PTB was further re-located a few meters upward (around $3 \mathrm{~m}$ above that of Shen et al., 2011, Fig. 4B), within the Dongchuan Fm, by Zhang et al. (2016), on the basis of a reevaluation of the plant content and the $\delta{ }^{13} \mathrm{C}$ trend recorded from the Xuanwei to the Dongchuan fms (Fig. 4B). However, based on the same $\delta{ }^{13} \mathrm{C}$ trend, Cui et al. (2016) modified the location of the PTB well below the boundary between the Kayitou and Dongchuan fms as proposed by Shen et al. (2011) and Zhang et al. (2016) at the Chahe section (Fig. 4C), but also questioned the exact location of the PTB in the Zhejue section (Fig. 5B). Moreover, for Zhang et al. (2016), the PTB would not crop out in the Zhejue section where only a small part of the Kayitou Fm is observed. The occurrence of rare fungal spores, marked only by the presence of few hyphae without Reduviasporonites (Bercovici et al., 2015), in the Zhejue and Chahe sections (noted "F" in Figs. 4C, 5B) is, however, considered by Cui et al. (2016) as the occurrence here of the "famous fungal spike event". This suggests that the PTB should be located near or above the top of the Xuanwei Fm in accordance with $\delta^{13} \mathrm{C}$ or Total Organic Content (TOC) trends. Moreover, these fungal remains are located $10 \mathrm{~m}$ below the proposed emplacement of this boundary in the Chahe section (Bercovici et al., 2015). All these conclusions have been drawn considering that all these deposits represent a continuous, non-deformed late Permian-Early Triassic sequence (Figs. 4A, B, C and 5A, B).

\section{Structural analysis}

The Chahe section is located within the complex tectonic zone represented by the major NE-SW trending, west-dipping Chahe left-lateral transpressive fault (Fig. 2A). The fault is separated into several parallel thrusts. West of Chahe, the Proterozoic to early Paleozoic bedrock is exposed along an east dipping, west verging thrust ( $F_{1}$ in Fig. 2A). The 
Chahe section itself is enclosed between the Chahe transpressive fault and a secondary eastverging thrust (respectively $\mathrm{F}_{2}$ and $\mathrm{F}_{3}$ on Fig. $2 \mathrm{~A}$ ). The Chahe fault system affects the whole Proterozoic to Middle Jurassic succession, and no evidence of Late Jurassic to younger deposits are preserved (Fig. 3A, B). Further to the east, the Zhejue section is located outside the main fault system (Fig. 2A).

The Chahe section is exposed for about $200 \mathrm{~m}$ along a road and forms a large anticline structure affected by several fold-break faults of unknown offset (Fig. 2B, C). This deformation is directly related to the major Mesozoic dextral transpressive Chahe fault $\left(\mathrm{F}_{2}\right)$ immediately to the east of the section (Fig. 2A). It also corresponds, in direction, to the regional NE-SW orientation of the folds and faults pattern that developed in the Daloushan region during the successive Early-Late Cretaceous, late Paleogene, and late Cenozoic compression phases (e.g. Deng et al., 2015). To the west, the smaller $F_{3}$ thrust fault also clearly affects the Permian succession (Fig. 2A) and a similar structure is again observed on a parallel section cropping out a few hundred meters to the east of the section (Fig. 6). Consequently, the Permian and Triassic succession exposed along the classical Chahe section is obviously affected by several major faults associated with folds and other minor fractures. Layer-parallel sliding most probably occurred within the silt and shale layers while the more competent sandstone beds are highly fractured and boudinaged. The lower part of the Xuanwei Fm (Fig. 7), from 0 to $55 \mathrm{~m}$ (Fig. 4D) is strongly deformed (below the Bed 34 of Bercovici et al., 2015, Fig. 4C). This deformed zone corresponds to the first $30 \mathrm{~m}$ of the section studied by Shen et al. (2011) and Zhang et al. (2016, Fig. 4B) and equivalent levels in previous publications (Fig. 4A). Many beds are discontinuous, sometimes duplicated, and stratigraphy has probably been cut out although it is not possible to assess the amount of missing material. Therefore, it is impossible to perform a continuous stratigraphic sedimentological study in this formation and, consequently, many results obtained from the 
Xuanwei Fm must be considered with caution. The only unquestionable information available is that the lower part of the Xuanwei Fm (below Bed 34, Fig. 4C) contains numerous macrofloral remains with a late Permian 'affinity'. Unfortunately, the palynofloral content is too badly preserved to be used for placing a biostratigraphic date. Additionally, due to the deformation, within the base of Xuanwei Fm in the Chahe section (Fig. 4D) neither the trend through time of the depositional environments nor a statistical analysis based on the variation of diversity within these floral assemblages can be validly supported (Peng et al., 2006; Yu et al., 2007; Zhang et al., 2006; Bercovici et al., 2015; Zhang et al., 2016; Cui et al., 2016). The top of the Xuanwei Fm is also affected by a major fault (Fig. 8) that offsets the succession from above $105 \mathrm{~m}$ (above Bed 67 of Bercovici et al. (2015), Fig. 4C; above around $81 \mathrm{~m}$ in Shen et al. (2011) and Zhang et al. (2016), Fig. 4B; and equivalent levels in previous publications; Fig. 4A). Finally, the upper part of the succession (Kayitou and Dongchuan fms) is also affected by numerous fold-accommodation faults, preventing any continuous logging and coherent stratigraphic analysis in the Kayitou and Dongchuan fms along that section (Fig. 8). Consequently, a sedimentological section from the Chahe outcrop can only be reconstructed from Bed 34 to Bed 67; that is only within the upper part of the Xuanwei Fm (Figs. 4D, 9, 10).

In the Zhejue section (Figs. 5C, 11), the lower part of the Xuanwei Fm. is folded, as indicated by variations in strike and dip along the profile, and largely faulted (Fig. 11B, C). Consequently, sedimentological logging is possible only from Bed 32 upwards.

\section{Sedimentological analysis}

The sedimentological analysis performed on the Chahe section (Figs. 9, 10) mainly displays claystone and siltstone, with a few fine-grained sandstone and coal beds. The 0.2-3 m thick siltstone and sandstone layers are composed of planar to sub-planar laminations, attributed to the tractive current of upper flow regime with very few current ripples and 3D 
megaripples. However, because of the deformation, the sedimentological structures are difficult to observe. These deposits form fining-upward sequences, from $0.50 \mathrm{~m}$ to $6 \mathrm{~m}$ thick. A complete sequence is composed, from the base to the top, of sandstone, siltstone, silty-clay and clay with thin coal beds. The depositional environment is typical of unconfined alluvial flow processes (North and Davidson, 2012) within a humid floodplain or ponds. The clay and silty-clay layers contain plant remains and the top of the clay layers is frequently bioturbated by thin root traces, attributed to Stigmaria sp. This sequence is frequently incomplete, lacking the basal sandstone to siltstone beds characteristic of distal humid alluvial plain deposits formed only by the finest-grained material.

As mentioned above, in the Chahe section the amount of stratigraphic material subtracted from the Kayitou and Dongchuan fms by faulting is unknown (Figs. 4D, 8). This prevents continuous logging in those two formations and the evolution of the depositional environment is impossible to define. However, above Bed 68, the sedimentation is coarsergrained with more silty and sandy beds attesting to more proximal deposits with few plant fragments (Beds 70-72), that are less abundant than in the previous beds (Fig. 10). This observation does not necessarily characterize a vegetation changeover across the PTB in this area but only a change in the sedimentation dynamic or in taphonomic style (e.g. Gastaldo et al., 2005); the higher proportion of plant fragments combined with coarser-grained sediment can be explained by an increase of sediment supply with an enhanced mechanical destruction of the plants. Moreover, the presence of Lepidopteris sp. at the base of Kayitou Fm (attributed to late Permian-Late Triassic) and conchostracans (Euestheria gutta, Beds 70-77; Chu et al., 2013), cannot be used to say that these beds belong to the Early Triassic. Indeed, only rare small fragments were found, so poorly preserved that it is not possible to determine the species. Therefore, the stratigraphic resolution for these beds is rather broad- from the late Permian to late Triassic (Yu et al., 2010, 2015). This, in combination with the lack of 
continuous section, does not allow us to place a precise location and age for the Triassic succession within this section. As a consequence, the sedimentological section reflects a late Permian distal humid alluvial plain environment, overlain by a strongly damaged succession of unknown age mainly formed by siltstone and sandstone deposits, with very few $\mathrm{dm}$ to $\mathrm{m}$ thick clay beds (Figs. 4D, 10).

In the Zhejue section (Figs. 5C, 11A), no facies variation is observed between the Xuanwei and Kayitou fms, but a sharp decrease in the floral diversity was observed above bed 42, although this interpretation is based only on highly fragmented remains (Bercovici et al., 2015). In consequence, no significant changes in depositional environment and plant content are observed between the Xuanwei and basal Kayitou fms. These formations display more sandy deposits than those observed in the Chahe section. The finer grained facies in the lower part of the section could explain the occurrence of better-preserved plants remains below Bed 42; the upper, coarser part supplying only small fragmentary remains. All this section must be considered as late Permian in age on the basis of its macrofloral content (Fig. 5C). Through correlation with the Chahe section, Peng and Shi (2009) considered the two claystone beds at the top of the section as the PTBST interval with a volcanic origin, while Zhang et al. (2016) described them as bauxite clay beds. However, we found no criteria (no zircon grain or plants) to demonstrate the occurrence of the PTB in the Zhejue section and, to a further extent, to correlate this section with the Chahe section further to the NW. Efforts to obtain zircon grains for U-Pb dating were unsuccessful.

In conclusion, from our structural analysis, the Chahe (Fig. 4D) and Zhejue (Fig. 5C) sections only display stratigraphically continuous outcrops within the late Permian succession. Moreover, from the sedimentological records and plant content, no accurate correlation between the Chahe and Zhejue sections can be defined. 


\section{Discussion}

With the exception of the works of Bercovici et al. (2015) and Zhang et al. (2016), none of the previous studies provided field pictures of the terrestrial PT outcrops in SE China. Although the Permian-Triassic succession exposed in the reference Chahe and Zhejue sections are strongly deformed, no structural data have been reported to age apart from mentioning the occurrence of so-called "minor deformation" (e.g. Bercovici et al., 2015). The Chahe section, which is the most deformed, is affected by a succession of fold-break faults linked to a regional-scale dextral transpressive fault system that developed during the Late Mesozoic tectonic event and was further reactivated during the Cenozoic. The section is divided into several tectonic compartments, which cut out or duplicate an unknown amount of stratigraphic material. Due to this complex deformation pattern, it is impossible to obtain a stratigraphically continuous, coherent set of data (geochemical, paleontological or sedimentological) across what is considered to be the Permian-Triassic succession in the Chahe and Zhejue sections. As a consequence, the previously published assumed stratigraphically continuous stable isotope $\left(\delta{ }^{13} \mathrm{C}\right.$ ) analyses (Peng et al., 2005; Zhang et al., 2016; Cui et al., 2016) should be interpreted with caution. For instance, the negative $\delta{ }^{13} \mathrm{C}$ excursion is located above the Bed 72, thus in the damaged zone (Figs. 4, 8, 10). Similarly, published statistical analyses on the variation of the diversity of fossil plants and pollen, again assumed to be performed on a stratigraphically continuous section (Peng et al., 2006; Yu et al., 2007; Bercovici et al., 2015), cannot provide an accurate estimate of the regional evolution of plant diversity from the late Permian to the Early Triassic. Indeed, the damaged zone, located within the Kayitou and Dongchuan fms, makes it impossible to detect and quantify a possible stratigraphic gap, thus impeding any description of the sedimentological trend of this succession (noted “1?" Fig. 3C). In consequence, only some parts of the $\delta{ }^{13} \mathrm{C}$ 
curves and trends of fossil evolution can be considered as valid within the late Permian Chahe section (i.e. only between the Beds 34 and 67, Fig. 2).

The exact location of the Permian-Triassic boundary, if it is present in these rocks, remains uncertain. Indeed, in the Chahe section, plant fragments and conchostracans contents at the base of the Kayitou Fm do not allow for a biostratigraphic age assignment. The fungal spore remains, documented at the very top of the Xuanwei Fm, supposedly marks the endPermian Event or "PTB fungal spike event" (Vajda and Bercovici, 2014; Bercovici and Vajda, 2016) by comparison with the occurrence of Reduviasporonites at the top of the Xuanwei Fm in sections located eastward (Mide and Jiucaichong sections). This interpretation is however strongly challenged by Hochuli (2016) who supports an erroneous determination of Reduviasporonites, probably mistakenly confused with recent contamination. Moreover, the supposed "fungal spore episode" in the Chahe and Zhejue sections is only marked by the presence of a few hyphae and a quantitative approach, necessary to demonstrate the occurrence of a true "spike", has not been possible due to the poor palynologic content. Hence, the studied level does not correspond, in fact, to the stratigraphic position of the PTB as proposed by Bercovici et al. (2015) and Cui et al. (2016) (Fig. 4C, 10A). Despite U-Pb dating of zircon grains in Bed 68 at the Chahe section (Yu et al., 2008; Shen et al., 2011), the interpretation of the maximum depositional age remains debatable due to potential reworking of the zircon grains (Hilton et al., 2004; He et al., 2010). The contemporaneity between the volcanism and the sedimentation is not certain and the ID-TIMS age estimate of $252.30 \pm$ 0.07 Ma provided by Shen et al. (2011) should be considered as a maximum depositional age instead of a true depositional age.

Regarding the Zhejue section, no criteria attest to the presence of the PTB or Triassic succession (noted "2?" in Fig. 3C). In fact, a more proximal environment than in the Chahe section explains the poor state of preservation of fossil plant remains. All these plants are of 
Permian affinity in the upper part of the formation, and cannot be used to locate precisely the PTB by assuming a decrease in plant diversity across this boundary. Moreover, $\delta^{13} \mathrm{C}_{\text {org }}$ or TOC measurements (Cui et al., 2016), as well as the presence of fungal remains, are not significant enough to determine if the PTB can be located in the Zhejue section. Indeed, the PTB is actually considered above the life crisis, by only $17 \mathrm{~cm}$ at Meishan, but as much as $60 \mathrm{~m}$ in Gondwanan sections (Retallack, 2013).

Finally, the contemporaneity between the marine and the terrestrial extinction events at the end of the Permian in southern China still needs to be clearly documented. As previously mentioned, due to the dense vegetal cover and tectonic deformation, the regional lateral and stratigraphic continuity between outcrops cannot be correctly assessed (noted "3?" in Fig. 3C). Under such conditions, the correlations between the already questionable "reference" terrestrial sections and outcrops within the marine PTB GSSP succession located eastwards are nearly impossible (noted "4?" in Fig. 3C). Moreover, no contact with the Eimeshan basalts is observed in the Chahe and Zhejue sections (noted "5?" in Fig. 3C). The proposed Permian to Early Triassic land-to-sea paleoenvironmental reconstruction (Peng et al. 2005; Yu et al., 2015; Bercovici et al., 2015) must be reconsidered based on regional tectonic and stratigraphic analyses. The inferred contemporaneity between the marine and terrestrial extinction events, recently questioned in the South African Karoo Basin (Gastaldo et al., 2015, 2017), must therefore be also re-evaluated in southern China. To conclude, most of the recent work in southern China, especially on the Chahe section, directed towards the definition of a continental parastratotype completing the Meishan PTB GSSP, must be reconsidered.

\section{Conclusion}

A detailed study of the Chahe and Zhejue sections considered, in numerous publications, as a reference for the continental Permian - Triassic transition in south China 
demonstrates for the first time that they are strongly affected by the polyphase deformation that affected the Guizhou and Yunan provinces during the Mesozoic and Cenozoic. These sections, especially Chahe, have been affected by a series of fold-break faults, dividing the succession into several tectonic compartments, making it is impossible to obtain a stratigraphically continuous section across the Permian and Triassic succession and, therefore, to locate accurately the Permian-Triassic boundary. From our sedimentological and structural analyses, the only continuous outcrops within the late Permian succession that can be observed in the field are restricted to a $50 \mathrm{~m}$ thick interval in Chahe and a $30 \mathrm{~m}$ thick interval in Zhejue. The Chahe section displays a distal humid alluvial plain environment dated from the late Permian based on mega- and microflora. These strata are overlain by a strongly damaged succession of unknown age; these beds contain conchostracans (Chu et al., 2013) and very rare highly fragmentary plant remains attributed to a time period extending from late Permian to Triassic. The Zhejue section displays more sandy deposits than the Chahe one, that are typical of unconfined flow processes especially in its upper part. This higher energy setting could explain the occurrence of only plant remains by a taphonomic bias (e.g. Gastaldo et al., 2005). As a consequence, on the basis of the macroflora, the Zhejue section must be considered as late Permian in age. Furthermore, from a biostratigraphic or sequence stratigraphy point of view, it is not possible to propose any accurate correlation between the Chahe and Zhejue sections or between these sections and other classical PT sections worldwide. They are, therefore, not suitable to base a discussion of the vertical and lateral evolution of depositional environments nor the geochemical trends throughout the PT boundary. Moreover, due to the strong tectonic deformation and the dense vegetal cover together with the strong outcrop alteration, it is not possible to establish any kind of large scale correlation between the outcrops in the Guizhou and Yunan provinces in order to discuss lateral depositional environment transition, or an onlap of these formations on the 
Sichuan-Yunnan old land mass to the west. Finally, in southern China, the contemporaneity between marine and terrestrial extinction events at the end of the Permian cannot be demonstrated from the sections in Guizhou and Yunan provinces. Therefore, the palaeoenvironment reconstruction and correlations from the terrestrial Guizhou and Yunnan provinces to the marine Meishan in the Zhejiang Province should be considered cautiously.

\section{Acknowledgments}

The authors thank M. Faure (University of Orléans, France) and G. Retallack (University of Oregon, USA) for their critical and constructive comments on an earlier version of this MANUSCRIPT AND THREE ANONYMOUS REVIEWERS FOR THEIR ADVICES ON THIS VERSION. OUR FIELDWORK WAS SUPPORTED BY THE NATIONAL SCIENCE FOUNDATION OF CHINA (NSFC- PROGRAMS N 41272372 AND 41572005). X. LE Coz and Y. Lepagnot are acknowledged for thin sections preparation, rock crushing and mineral separation respectively.

\section{References}

Bercovici, A., Cui, Y, Forel, M.B., Yu, J., Vajda, V., 2015. Terrestrial paleoenvironment characterization across the Permian-Triassic boundary in South China. Journal of Asian Earth Sciences, 98, 225-246.

Bercovici, A., Vajda, V., 2016. Terrestrial Permian-Triassic boundary section in south China. Global and Planetary Change. Doi:10.1016/j.glopacha.2016.05.010.

Bureau of Geology and Mineral Resources of Guizhou Province, 1980. Geological map of Guizhou, SCALE 1:200 000, G-48-XIV, Geological Publishing House, China.

Burgess, S. D., S. A. Bowring, and S. -Z. Shen. 2014. High-precision timeline for Earth's most severe extinction. Proceedings of the National Academy of Sciences 111:3316-3321.

Chen, A., 1999. Mirror-image thrusting in South China Orogenic Belt: tectonic evidence from western Fujian, southeastern China. Tectonophysics, 305, 497-519. 
Chu, D.-L., Tong, J.-N., Yu, J.-X., Song, H.-J., Tian, L., 2013. The COnCHOSTRACAN FAUNA FROM THE KAYITOU FORMATION OF WESTERN GUIZHOU, CHINA. ACTA

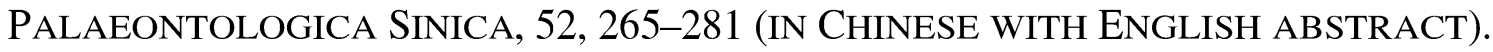

Cui, Ying, Bercovici, A., Yu, Jianxin, Kump, L., Freeman, K., Su, Shangguo, Vajda, V., 2016. Carbon cycle perturbation expressed in terrestrial Permian-Triassic boundary sections in south China. Global and Planetary Change, 148, 272-285.

Corfu, F., 2013. A century of U-Pb geochronology: The long quest towards concordance. Geological Society of America Bulletin, 125, no. 1-2, 33-47, doi: 10.1130/B30698.1.

Dickinson, W.R., Gehrels, G.E., 2009. Use of U-Pb ages of detrital zircons to infer maximum depositional ages of strata: A test against a Colorado Plateau Mesozoic database. Earth and Planetary Science Letters, 288, 1-2, 115-125, doi: 10.1016/j.epsl.2009.09.013.

Faure, M., Wei Lin, Yang Chu and Lepvrier C., 2016. Triassic tectonics of the southern margin of the South China Block. Comptes Rendus Géosciences, 38, 5-14.

Gastaldo, R.A., Adendorff R., Bamfor M., Labandeira, C.C., Neveling J., and Sims, H. 2005. Taphonomic Trends of Macrofloral Assemblages Across the Permian-Triassic Boundary, Karoo Basin, South Africa. PALAIOS, 2005, v. 20, p. 479-497.

Gastaldo, R.A., Kamo, S.L., Neveling J., Geissman J.W., Bamford M., Looy, C.V., 2015. Is the vertebrate-defined Permian-Triassic boundary in the Karoo Basin, South Africa, the terrestrial expression of the end-Permian marine event?. Geology, 43, 939-942.

Gastaldo, R.A., Neveling, J., Looy, C.V., Bamford, M.K., Kamo, S.L., and Geissman, J.W., 2017. Paleontology of the Blaauwater 67 Farm, South Africa: Testing the Daptocephalus/Lystrosaurus Biozone Boundary in a Stratigraphic Framework: PALAIOS, v. 34, p. 349-366. 
Geological maps of Guizhou and Yunan provinces, PRC, 1/500000, 1986.

Glen, J.M.G., Nomade, S., Lyons, J.J., Metcalfe, I., Mundil, R., Renne, P.R., 2009. Magnetostratigraphic correlations of Permian-Triassic marine-to-terrestrial sections from China. Journal of Asian Earth Sciences, 36, 521-540.

He, Bin, Xu, Yi-Gang, Huang, XiaoLong, Luo, Zhen-Yu, Shi, Yu-Ruo, Yang, Qi-Jun, Yu, SongYue, 2007. Age and duration of the Emeishan flood volcanism, SW China: geochemistry and SHRIMP zircon U-Pb dating of silicic ignimbrites, post-volcanic Xuanwei Formation and clay tuff at the Chaotian section. Earth and Planetary Science Letters, 255, 306-323.

He, Bin, Xu, Yi-Gang, Zhong, Yu-Ti,ng, Guan, Jun-Peng, 2010. The Guadalupian-Lopingian boundary mudstones at Chaotian (SW China) are clastic rocks rather than acidic tuffs: implication for a temporal coincidence between the end-Guadalupian mass extinction and the Emeishan volcanism. Lithos, 119, 10-19.

Hilton, J., Shi-Jun, W., Galtier, J., Glasspool, I., Stevens, L., 2004. An UpPeR PERMIAN PERMINERALIZED PLANT ASSEMBLAGE IN VOLCANICLASTIC TUFF FROM THE XuANWEI Formation, Guizhou PROVInCE, SOUTHERn CHINA, AND ITS PALAEOFLORISTIC SIGNIFICANCE. GEOLOGICAL MAGAZINE 141, 661-674. DOI:10.1017/S0016756804009847

Hochuli, P. A., 2016. Interpretation of "fungal spikes" in Permian-Triassic boundary sections. Global and Planetary Change. Doi:10.1016/j.glopacha.2016.05.002.

Li, ZHENG-XIANG, Li, XIAN-HUA, 2007. Formation of the 1300-km-wide intracontinental orogen and post-orogenic magmatic province in Mesozoic South China: a flat-slab subduction model. Geology, 35, 179-182.

LiU LiPING, Li SANZHONG, DAI LiMING, SuO YANHUI, LiU Bo, ZHANG GUOWEI, WANG YUEJUN, AND LIU ENSHAN, 2012. GEOMETRY AND TIMING OF MESOZOIC DEFORMATION IN THE WESTERN PART OF THE XUEFENG TECTONIC BELT, SOUTH 
CHINA: IMPLICATIONS FOR INTRA-CONTINENTAL DEFORMATION. JOURNAL OF ASIAN ERATH SCIENCES, VOL. 49, PP. 330-338.

North, C.P., Davidson, S., 2012. Unconfined alluvial flow processes: recognition and interpretation of their deposits, and significance for palaeogeographic reconstruction. Earth-Science Review, 111, 199-223.

Peng, Yuanqiao, Yu, Jianxin, Gao, Yongqun, Yang, Fengqing, 2006. Palynological assemblages of non-marine rocks at the Permian-Triassic boundary, western Guizhou and eastern Yunnan, South China. Journal of Asian Earth Sciences, 28, 291-305.

Peng, Yuanqiao, Zhang, Suxin, Yu, Tianxin, Yang, Fengqing, Gao, Yongqun, Shi, G.R., 2005. High-resolution terrestrial Permian-Triassic eventostratigraphic boundary in western Guizhou and eastern Yunnan, southwestern China. Palaeogeography, Palaeoclimatology, Palaeoecology, 215, 285-295.

Peng, Yuanqiao, Shi, G.R., 2009. Life crises on land across the Permian-Triassic boundary in South China. Global and Planetary Change, 65, 155-165.

Richardson, N.J., Densmore, A.L., Seward, D., Fowler, A., Wipf, M., Ellis, M.A., Li, Y., Zhang, Y., 2008. Extraodinary denudation in the Sichuan Basin: Insights from lowtemperature thermochronology adjacent to the eastern margin of the Tibetan Plateau. Journal of Geophysical Research, 113, B04409, doi:10.1029/2006JB004739.

Retallack, G.J., 2013. Permian and Triassic greenhouse crises. Gondwana Research, 24, 90103.

Shen, S.z., Crowley, J.L., Wang, Y., Bowring, S.A., Erwin, D.H., Sadler, P.M., Cao, C.q., Rothman, D.H., Henderson, C.M., Ramezani, J., Zhang, H., Shen, Y., Wang, X.d., Wang, W., Mu, L., Li, W.z., Tang, Y.-g., Liu, X.1., Liu, L.j., Zeng, Y., Jiang, Y.f., Jin, Y-g., 2011. Calibrating the end-Permian Mass Extinction. Science, 334, 1367-1372, doi:10.1126/science.1213454. 
Twitchett, R.J., Looy, C.V., Morante, R., Vissher, H., Wignall, P.B., 2001. Rapid and synchronous collapse of marine and terrestrial ecosystems during the end-Permian biotic crisis. Geology, 29, 351-354.

Vajda, V., Bercovici, A., 2014. The global vegetation pattern across the CretaceousPaleogene mass extinction: a template for the other events. Global and Planetary Change, $12,29-49$.

WANG, HaO, ShaO, LONGYI, HaO, Liming, ZHANG, PENGFEI, GLASSPOOL, I.J., Wheeley, J.R., Wignall, P.B., Yi, Tongsheng, Zhang, MingQuan, Hilton, J., 2001. SEDIMENTOLOGY AND SEQUENCE STRATIGRAPHY OF THE LOPINGIAN (LATE PERMIAN) COAL MEASURES IN SOUTHWESTERN CHINA. INTERNATIONAL JOURNAL OF COAL GEOLOGY, 85, 168-183.

XIONG, CONGHUI, WANG, QI, 2011. PERMIAN-TRIASSIC LAND-PLANT DIVERSITY IN SOUTH CHINA: WAS THERE A MASS EXTINCTION AT THE PERMIAN-TRIASSIC BOUNDARY?. PALEOBIOLOGY, 37, 157-167.

Yan, DAn-Ping, Zhou, MeI-Fu, Song, Hong-Lin, Wang, Xin-Wen, Malpas, J., 2003. Origin and tectonic significance of a Mesozoic multi-layer over-thrust system within the Yangtze Block (South China). Tectonophysics, 361, 239-254.

Yin, Hong-Fu, Zhang, Ke-Xin, Tong, Jin-Nan, Yang, Zun-Yi, Wu, Shun-Bao, 2001. The Global Stratotype Section and Point (GSSP) of the Permian-Triassic boundary. Episodes, $24,102-114$.

Yu, Jianxin, Peng, Yuanqiao, Zhang, Suxin, Yang, Fengqing, Zhao, Quanming, Huang, Qisheng, 2007. Terrestrial events across the Permian-Triassic boundary along the Yunnan-Guizhou border, SW China. GloBAL AND PlaneTARY CHANGE, 55, 193-208.

Yu, Jianxin, Li, HuiMin, Zhang, SuXin, Yang, FengQing, Feng, QingLai, 2008. Timing of the terrestrial Permian-Triassic boundary biotic crisis: Implications from U-Pb dating of authigenic zircons. Science in China Press, 51, 11, 1633-1645. 
Yu, Jianxin, Broutin, J., Huang, Qisheng, Grauvogel-Stamm, L., 2010. Annalepis, a pioneering lycopsid genus in the recovery of the Triassic land flora in South China. Comptes Rendus Palevol, 9, 479-486.

Yu, Jianxin, Broutin J., Chen, Zhong-Qiang, Shi, Xiao, Li, Hui, Chu, Daoliang, Huang, Qisheng, 2015. Vegetation changeover across the Permian-Triassic Boundary in Southwest China Extinction, survival, recovery and palaeoclimate: A critical review. Earth Science Reviews, 149, 203-224.

WANG YueJun, FAN WeIMING, ZhANG GUOWEI AND ZHANG YANHUA, 2013. PHANEROZOIC TECTONICS OF THE SOUTH CHINA BLOCK: KEY OBSERVATIONS AND CONTROVERSIES. GONDWANA RESEARCH, VOL. 23, PP. 1273 - 1305.

Zhang, Suxin, Peng, Yuanqiao, Yu, Jianxin, Lei, Xinrong, Gao, Yongqun, 2006.

Characteristics of claystones across the terrestrial Permian-Triassic boundary: evidence from the Chahe section, western Guizhou, South China. Journal of Asian Earth Sciences, $27,358-370$.

Zhang, Hua, Cao, Chang-qun, Liu, Xiao lei, Mu, Lin., Zheng, Quan feng, Liu, Feng, Xiang, Lei, Liu Lu jun, Shen, Shu-zhong, 2016. The terrestrial end-Permian mass extinction in South China. Palaeogeography, Palaeoclimatology, Palaeoecology, 448, 108-124.

Zhou, X.M., Sun, T., Shen, W.Z., Shu, L.S., Niu, Y.L., 2006. Petrogenesis of Mesozoic granitoids and volcanic rocks in South China: a response to tectonic evolution. Episodes, $29,26-33$

\section{FIGURE CAPTIONS}

Figure 1. Topographic map of SE China showing the location of the studied area as well as the main tectonic structures. Faults with plain black triangles are Cenozoic active thrusts, opened black triangles indicate Mesozoic thrusts. ZLF: Ziyun - Luodian fault; RRF: Red River fault. 
Figure 2. A: Geological map of the studied area simplified from the Bureau of Geology and Mineral Resources of Guizhou Province (1980). See location on figure 3B; B: General view of the Chahe outcrop; C: Interpreted geological section. Labels I to VII refer to the main features illustrated on pictures in Figs. 7, 8, 9 and 10. General bedding attitude is indicated by white dotted lines.

Figure 3. A: Simplified geological map of the Chahe area modified from the Geological maps of Guizhou and Yunan provinces, PRC, 1/500000, 1986. The white line A to D indicates the track of the geological section in figure $3 \mathrm{~B}$. The dotted line $\mathrm{A}-\mathrm{A}^{\prime}$ indicates the track of the lithostratigraphic section of Peng et al., (2005). B: General geological section (see location on Fig. 3A), showing the major tectonic structures affecting the late Paleozoic - Mesozoic cover sequence in the Chahe region. C: Lithostratigraphy of western Guizhou and eastern Yunnan at the PTB along the track indicated on figure 3A (Peng et al., 2005); note that the observation obtained on the Chahe and Zhejue sections have been projected on a E-W track.

Figure 4. Comparison between the sedimentological sections and stratigraphic attributions of the Chahe section proposed by different authors. A: The thickness of this section is not indicated in these references, with the exception of Peng and Shi (2009) who attribute a thickness of $40 \mathrm{~m}$ to sediments on both sides of the PTBST allowing for a thickness estimation and rough comparison with the other published sections (B, C) and our data (D). Figure 5: Comparison, for the Zhejue section, of the sedimentological formations and their stratigraphic attributions as proposed by different authors. A: The thickness of this section is not indicated in these references, with the exception of Peng and Shi (2009) who attribute a thickness of $20 \mathrm{~m}$ to sediments on both sides of the PTBST allowing for a thickness estimation and rough comparison with the other published sections (B) and our data (C). Figure 6: Similar section, parallel to that of figure 2B and cropping out on the other side of the Chahe valley (Fig. 2A). A: General view of the section; B-D: Photographs showing some 
of the deformational features. General bedding attitude is shown by white dotted lines; faults are indicated as black lines.

Figure 7: Photographs showing some of the deformational features within the basal part of the Xuanwei Fm in the Chahe outcrop (below Bed 34 Fig. 4C, D). A: Geological section (see Fig. 2). Label I to VII refer to tectonic compartments; B-G: detailed pictures, located on the geological section (A) in the white boxes. General bedding attitude is shown by white dotted lines; faults are indicated as black lines.

Figure 8: Photographs showing some of the deformational features in the upper part of the Chahe outcrop, i.e. upper part of the Xuanwei Fm, Kayitou Fm and lower part of the Dongchuan Fm. A: Geological section (see Fig. 2). Label I to VII refer to tectonic compartments; B-E: detailed pictures, located on the geological section (A) in the white boxes. General bedding attitude is shown by white dotted lines; faults are indicated as black lines.

Figure 9: OUTCROPS FROM THE CHAHE SECTION SHOWING THE BASE OF THE LESSDEFORMED COMPARTMENT OF THIS SECTION (XUANWEI FM.); A:

SEDIMENTOLOGICAL SECTION FROM BERCOVICI ET AL. (2015); B: OUR SECTION (FIG. 4D); C: PHOTOGRAPH SHOWING DETAIL OF THE LAST FAULT ZONE OF COMPARTMENT IV (FIG. 7G) DISPLAYING DISCONTINUOUS BEDS although it is not possible to assess the amount of missing material; D-E: LOCATION OF THE BEGINNING OF THE CONTINUOUS SEDIMENTOLOGICAL SECTION; F: GENERAL VIEW OF THE SECTION. SEE FIGURE 7 FOR GENERAL CROSS-SECTION. SECTION CONTINUES ON FIGURE 10. General bedding attitude is shown by white dotted lines; faults are indicated as black lines.

Figure 10: THE XUANWEI AND KAITOU FORMATIONS AND THE END OF THE SEDIMENTOLOGICAL SECTION IN THE CHAHE OUTCROP; A: SEDIMENTOLOGICAL SECTION FROM BERCOVICI ET AL. (2015); B: OUR SECTION (FIG. 4D); C: GENERAL VIEW OF THE SECTION; D, F: SOME DETAILS OF DEFORMATION IN BED 68; F: DETAIL 
OF FAULT MIRROR. SEE FIGURE 8 FOR GENERAL CROSS-SECTION. General bedding attitude is shown by white dotted lines; faults are indicated as black lines.

Figure 11: Zhejue outcrop; A: Sedimentological section from Bercovici et al. (2015).

Strikes and dips are from this study and from Bercovici et al., 2015 (number in brackets); B to

D: Detailed pictures of the section. General bedding attitude is shown by white dotted lines; faults are indicated as black lines. 


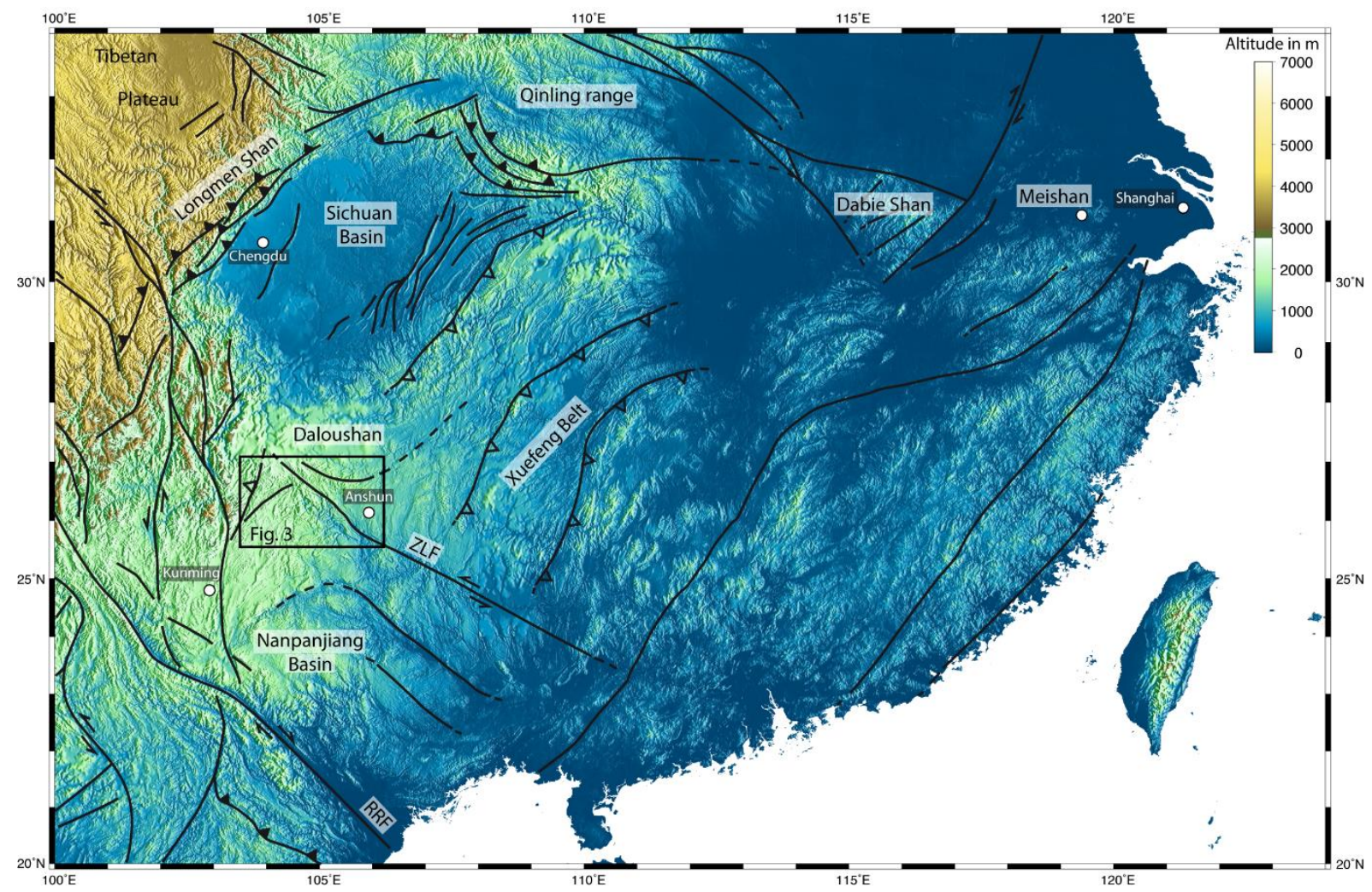

Bourquin et al., Figure 1 


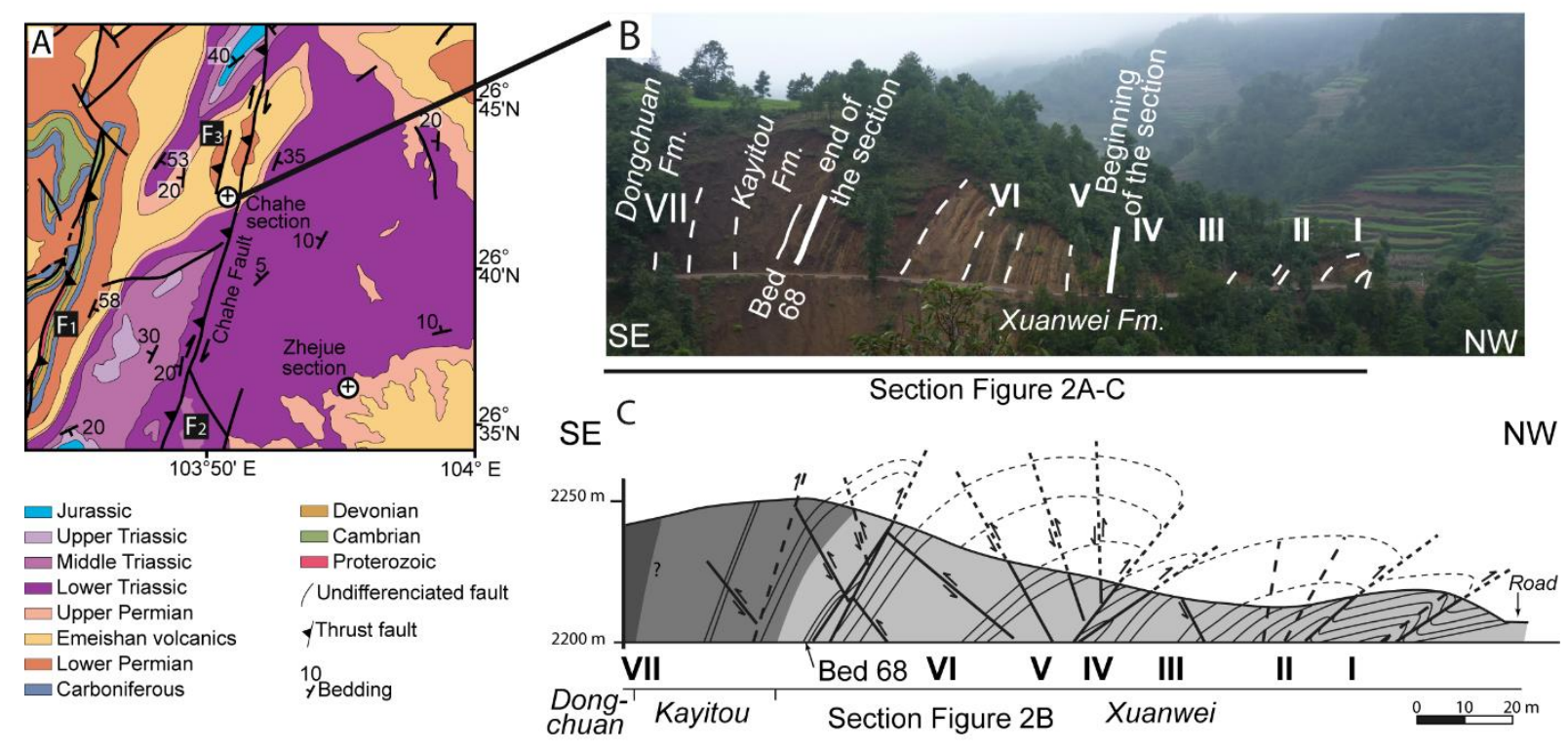

Bourquin et al., Figure 2 


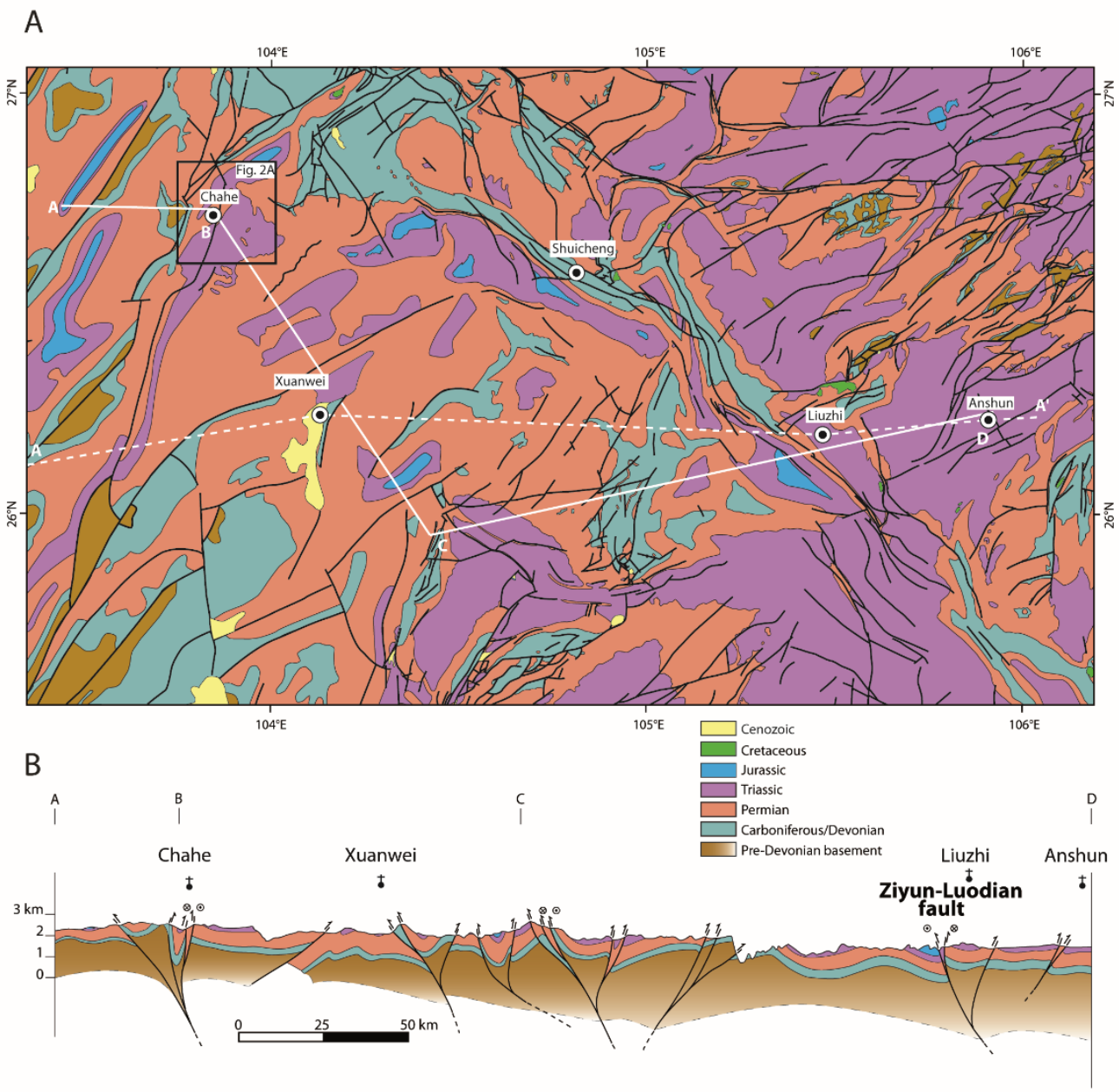

C

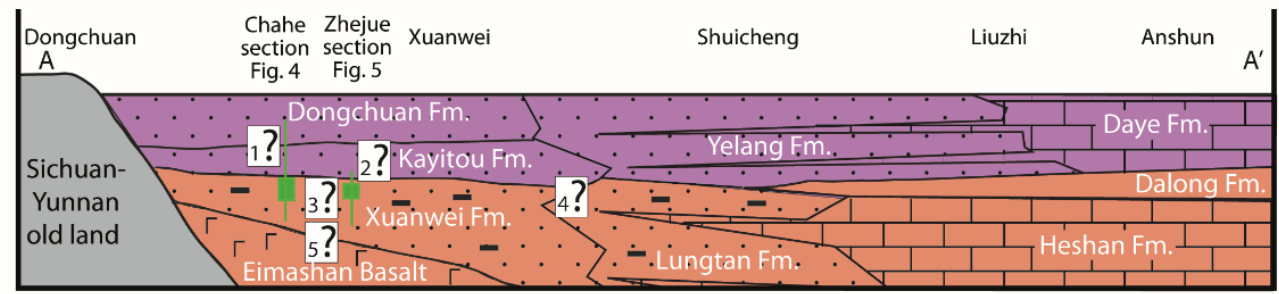

.....- facies boundary sandstone/silstone

- coal siliceous mudstone and chert $\rightleftarrows$ limestone

2? no data (see text for explanation) section location : | bibliography data

this work

Bourquin et al., Figure 3 


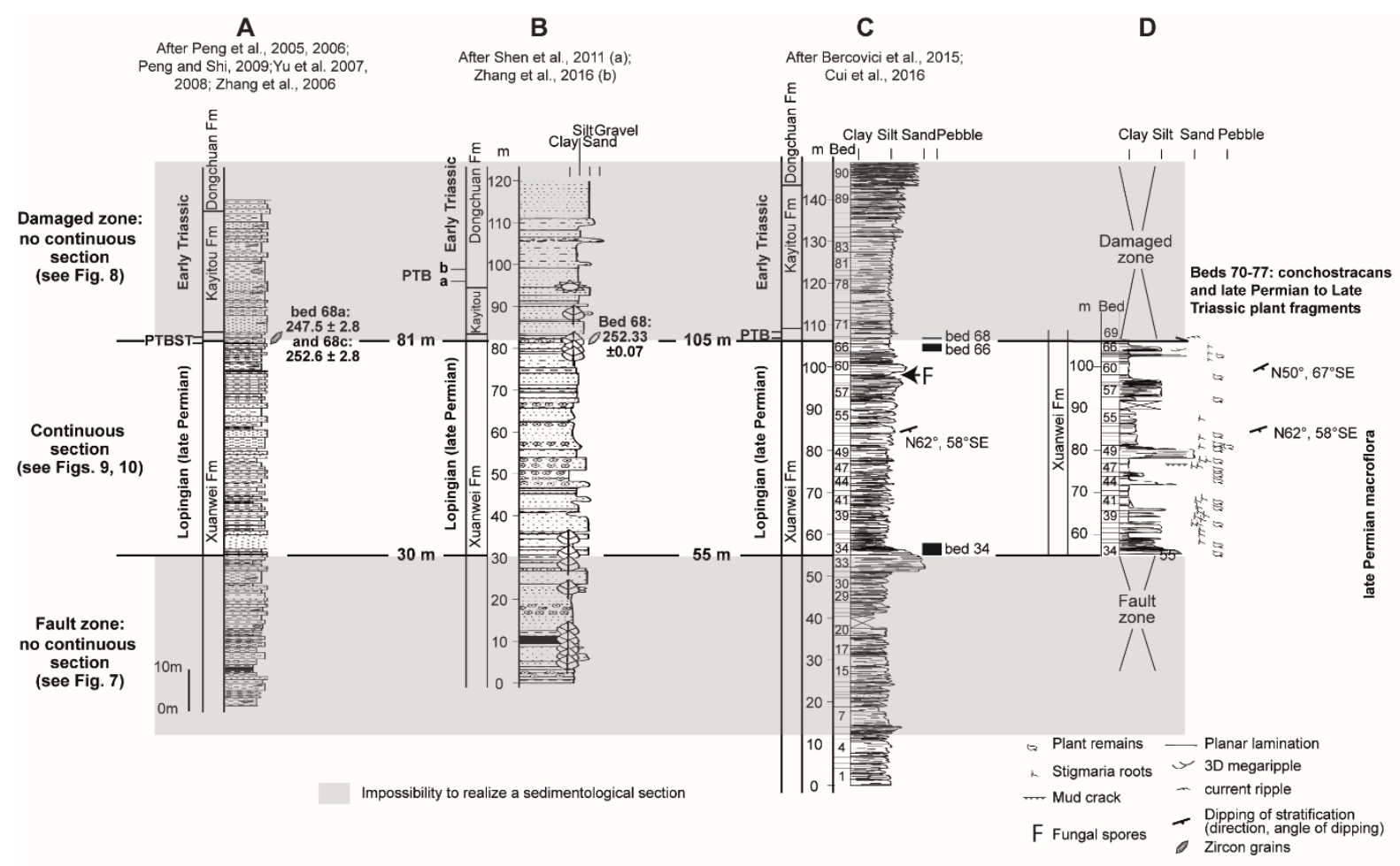

Bourquin et al., Figure 4 
A

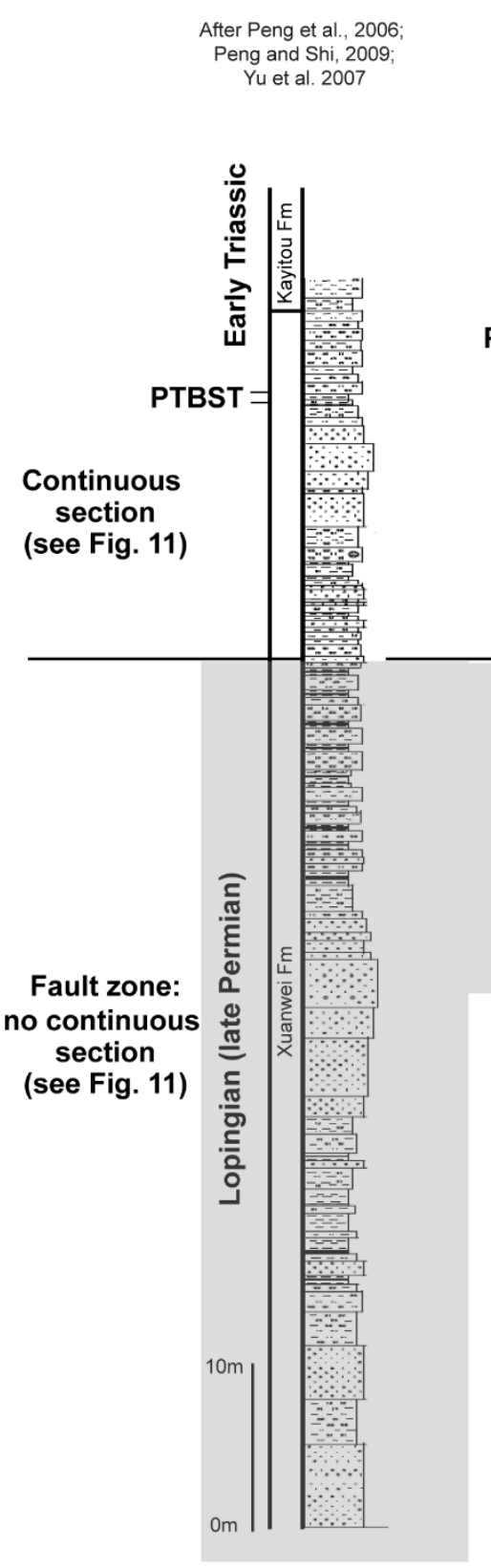

B

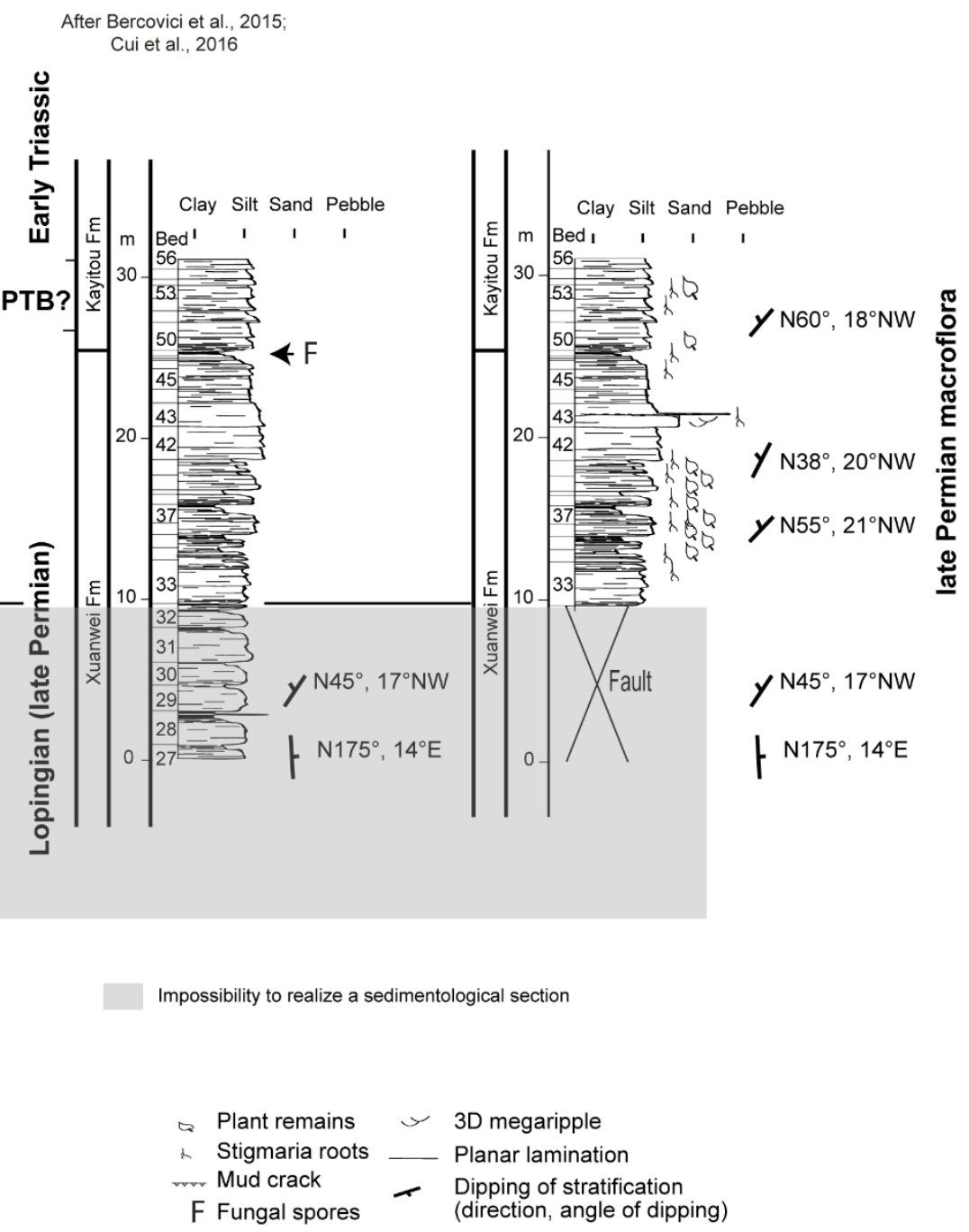

Bourquin et al., Figure 5 

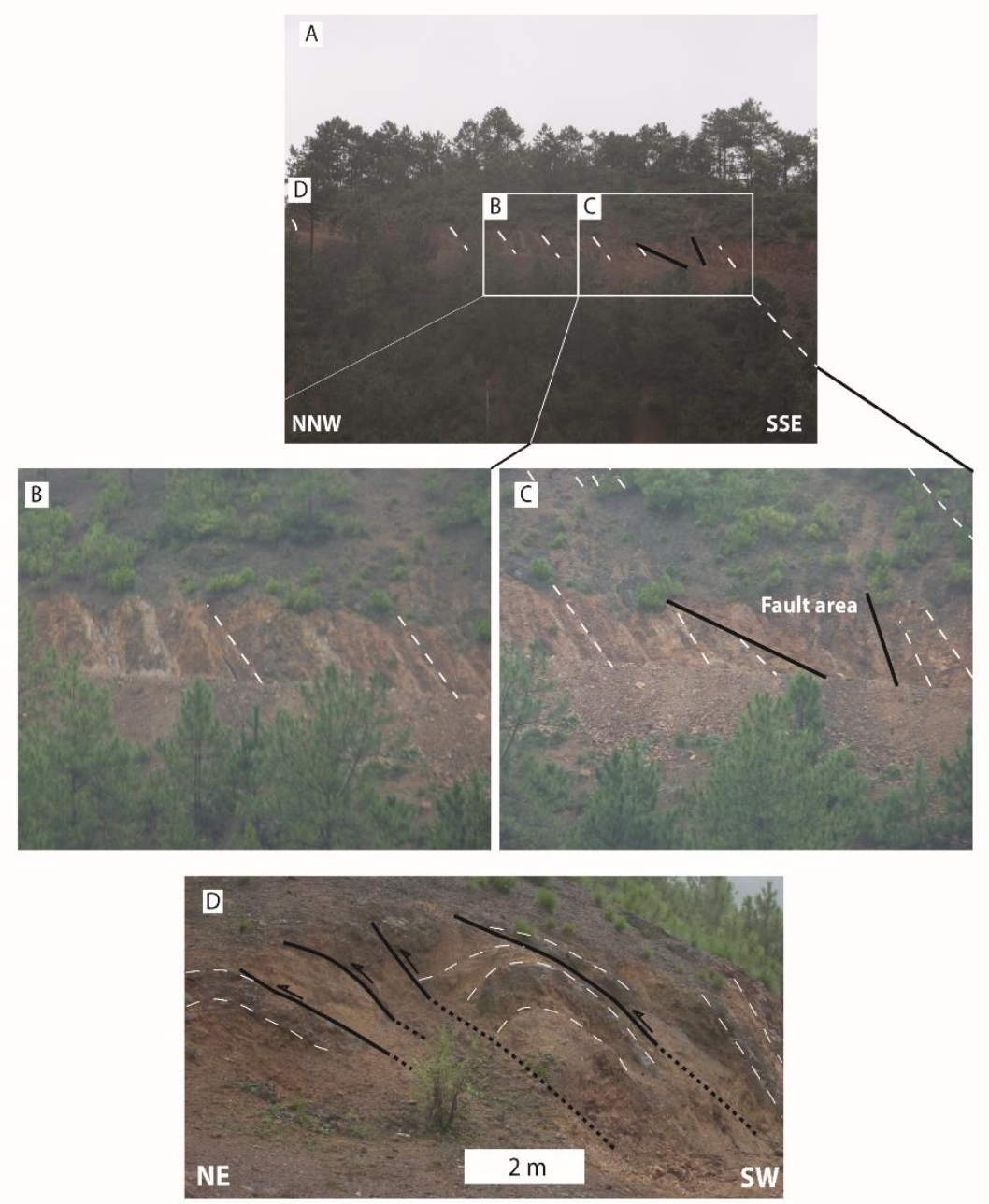

Bourquin et al., Figure 6 

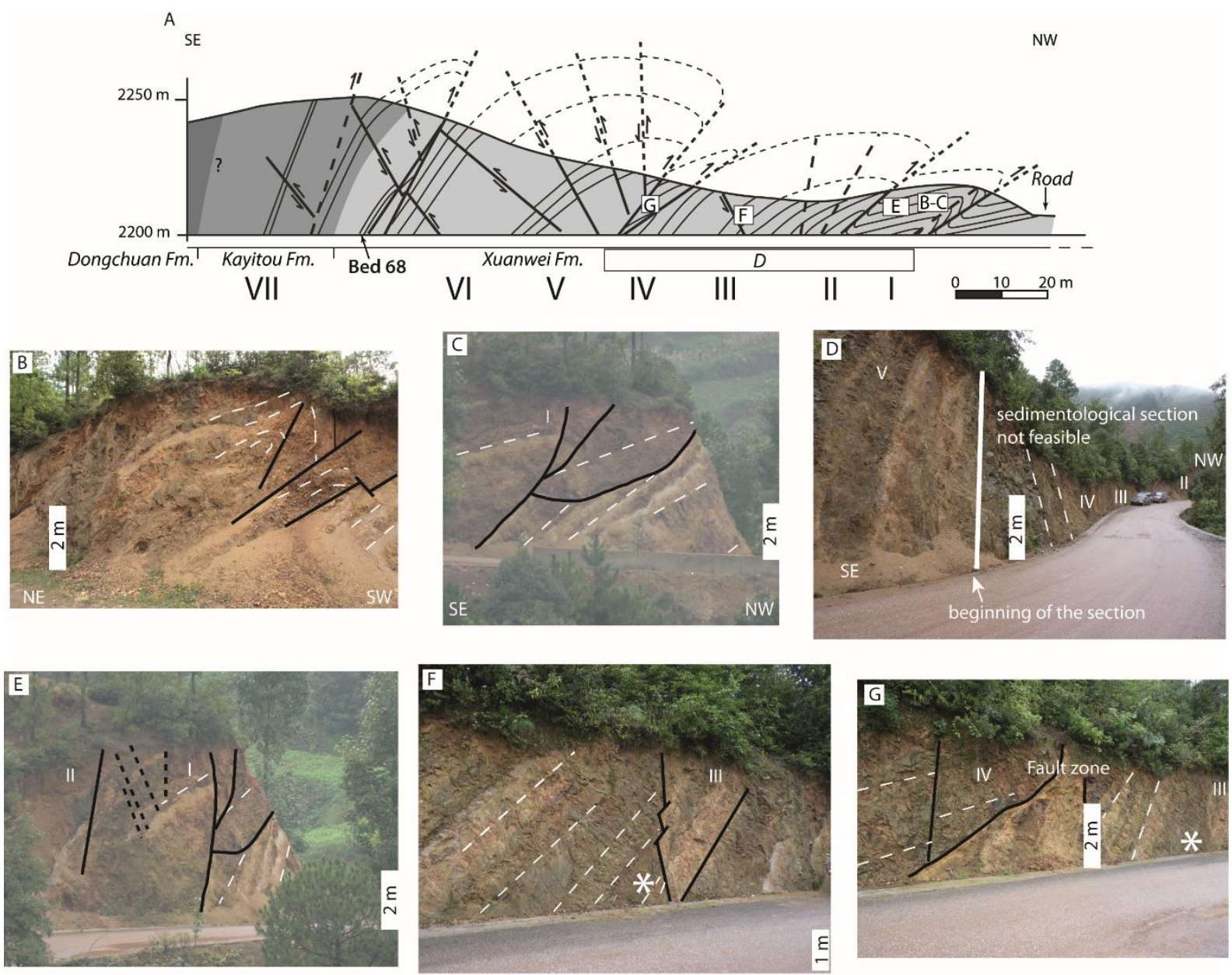

Bourquin et al., Figure 7 


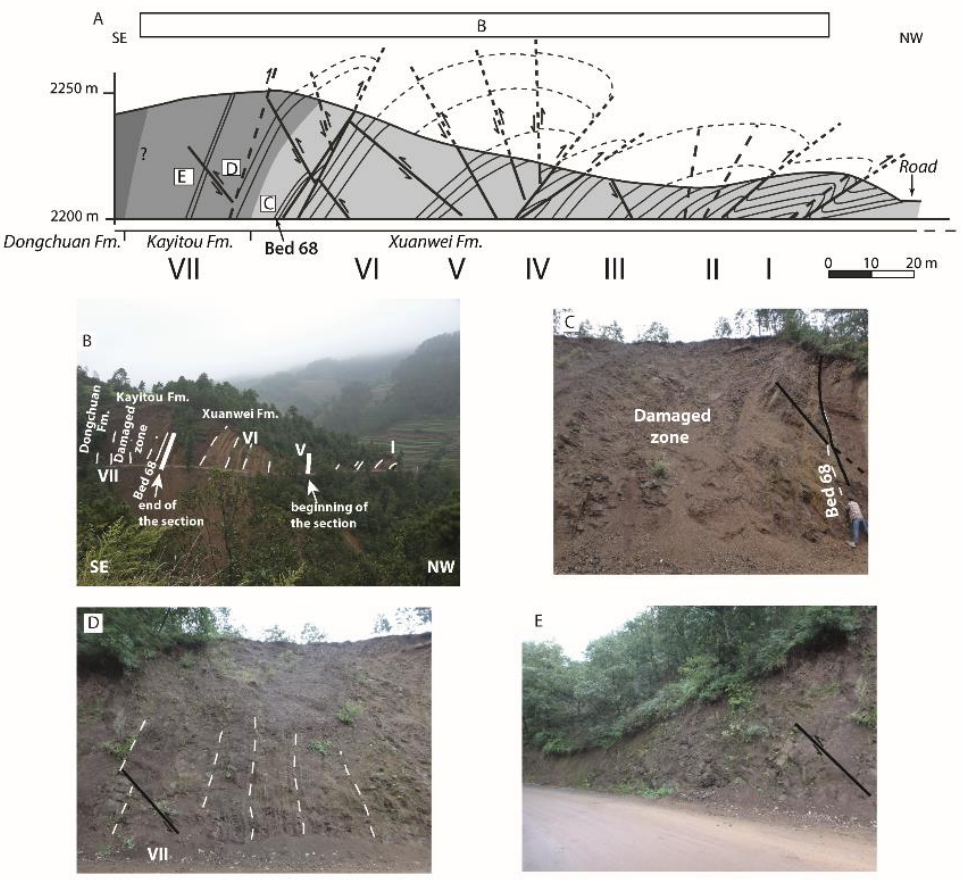

Bourquin et al., Figure 8 


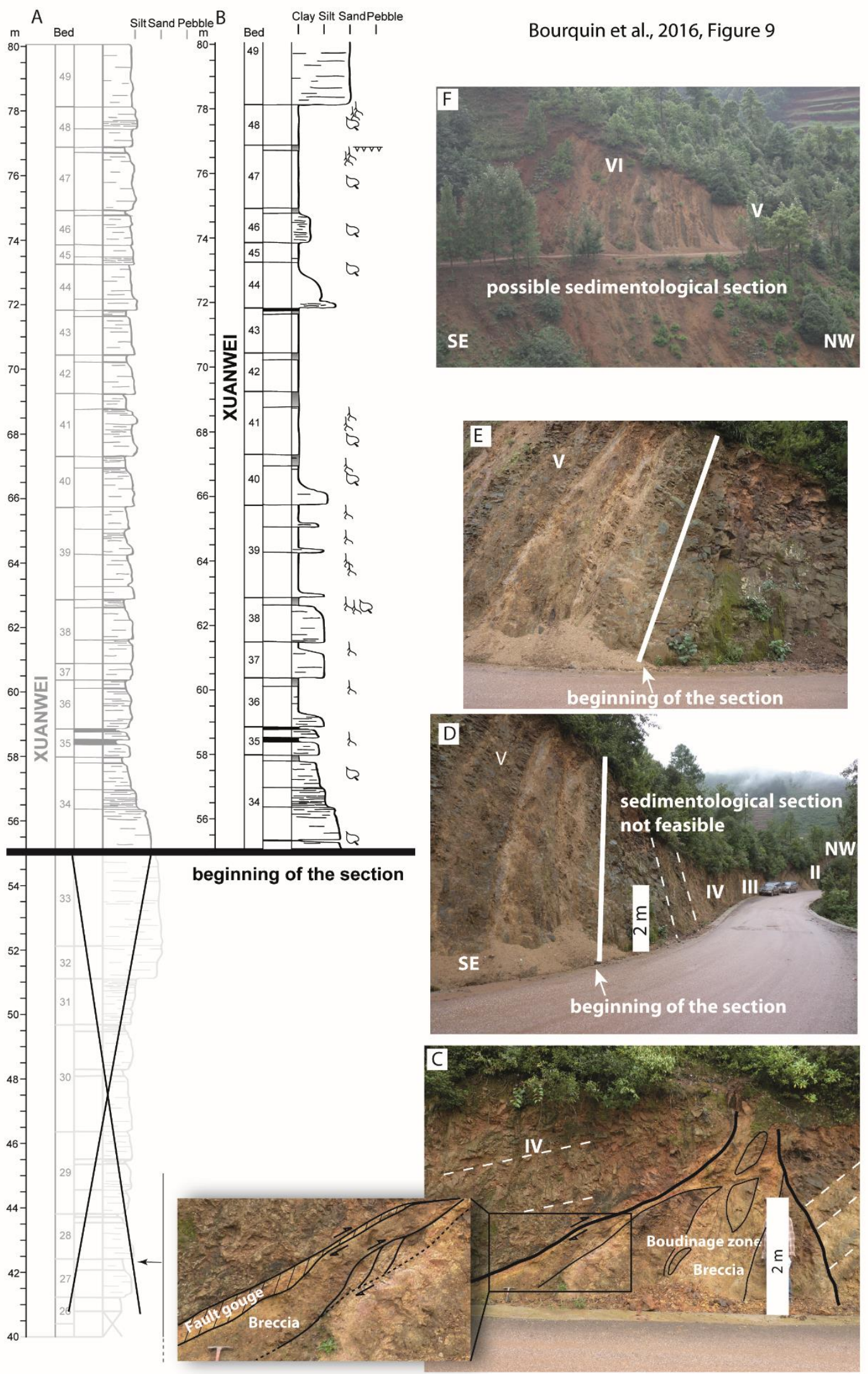




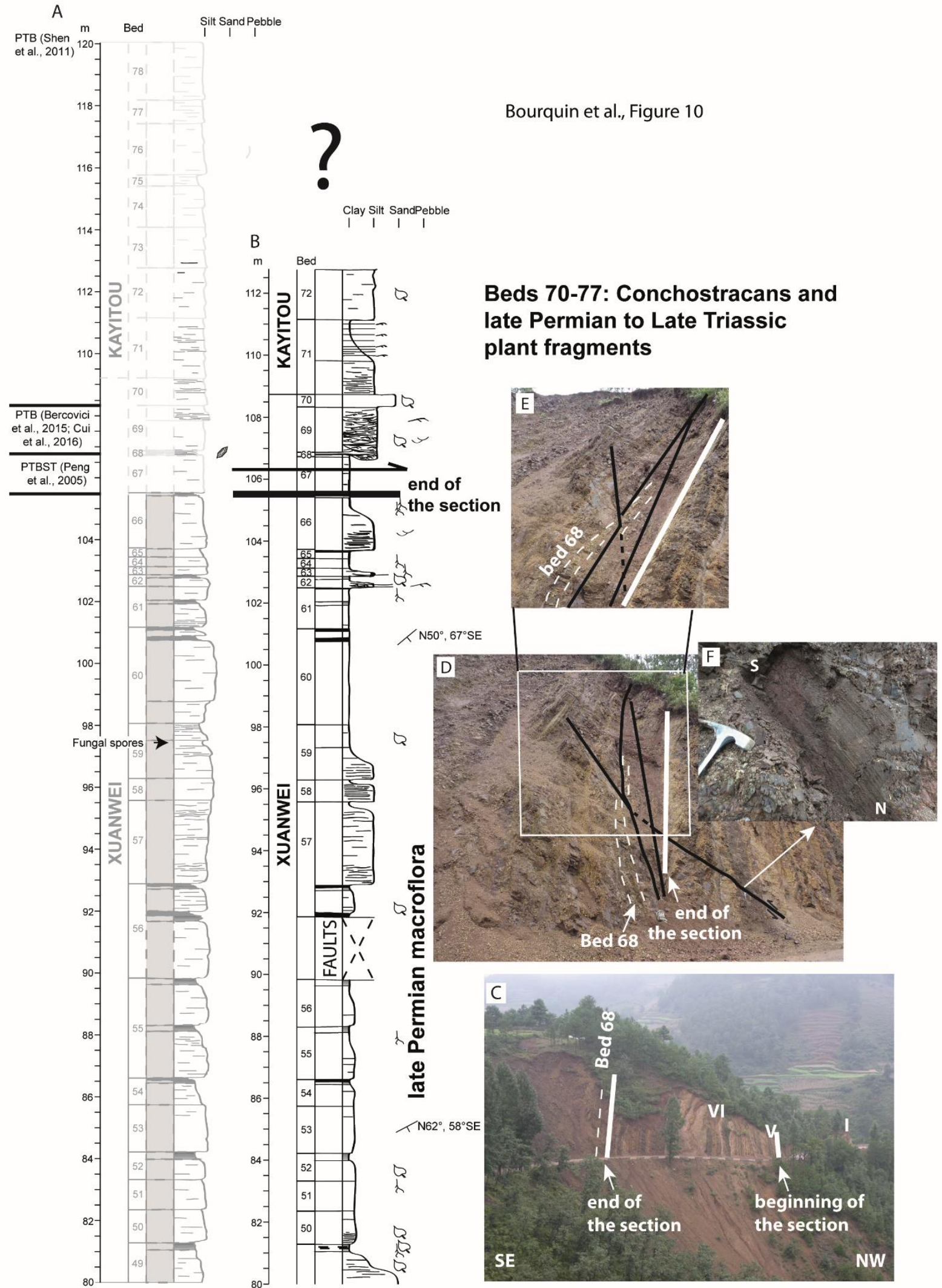




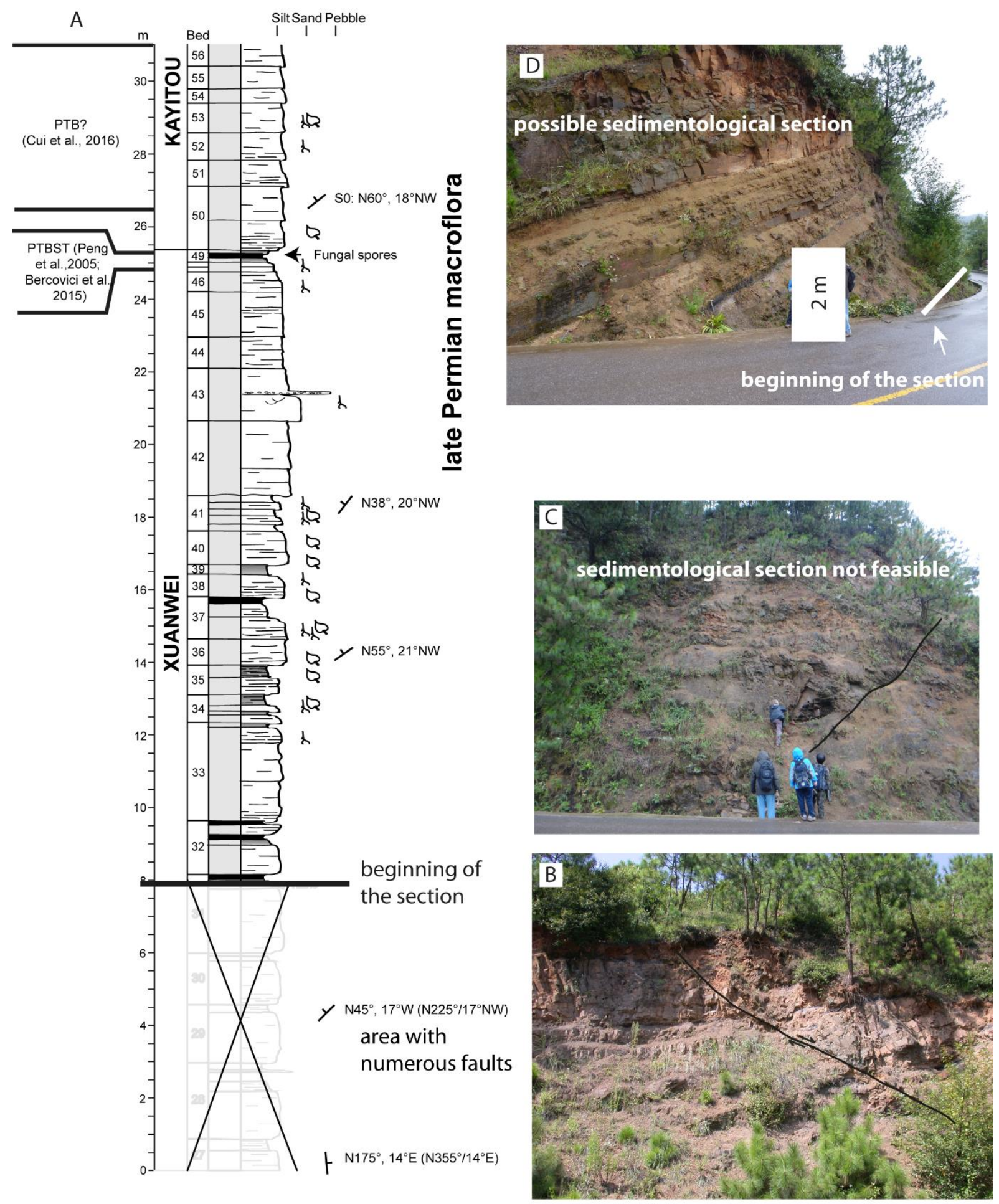

Bourquin et al., Figure 11 


\section{HIGHLIGHTS}

- Detalled ANAlysis of ChaHe AND Zhejue SECTIONS IN EASTERN YUNNAN AND WESTERN GUIZHOU

- New COnsiderations about Terrestrial Permian-Triassic BOUNDARY IN SOUTHERN CHINA

- IMPLICATIONS FOR PERMIAN-TRIASSIC PALAEOENVIRONMENT RECONSTRUCTIONS IN SE CHINA

- NeED OF RE-EVAluation OF THE CORRELATION WITH THE MEISHAN MARINE SECTION 